\title{
TTR
}

Traduction, terminologie, re?daction

\section{Activist Translation in an Era of Fictional Law}

\section{Robert F. Barsky}

Volume 18, numéro 2, 2e semestre 2005

Traduction engagée

Translation and Social Activism

URI : https://id.erudit.org/iderudit/015745ar

DOI : https://doi.org/10.7202/015745ar

Aller au sommaire du numéro

\section{Éditeur(s)}

Association canadienne de traductologie

ISSN

0835-8443 (imprimé)

1708-2188 (numérique)

Découvrir la revue

Citer cet article

F. Barsky, R. (2005). Activist Translation in an Era of Fictional Law. TTR, 18(2), 17-48. https://doi.org/10.7202/015745ar

\section{Résumé de l'article}

La traduction engagée à une époque de droit fictif - Cet article propose que les traducteurs militants s'engagent dans les domaines du droit tels que le traitement réservé aux immigrants clandestins ou sans papiers, car ils peuvent y agir en tant que véritables intermédiaires, au-delà de l'acte de substitution d'un élément lexical par un autre. Cependant, cette forme d'engagement, comme toute activité discrétionnaire, doit être pratiquée pour des causes élevées, telles que la défense des droits de l'homme chez les exclus de la société. En d'autres mots, l'engagement doit être accompagné de bonne foi, parce que « l'engagement » peut aussi nuire activement à la personne pour laquelle le traducteur accomplit sa tâche. Autrement dit, lorsque le " traducteur » décide de devenir " interprète ", la subjectivité du second risque de l'emporter sur « l'objectivité » du premier, ce qui peut engendrer des conséquences néfastes. Cet article préconise l'engagement plutôt que la fidélité machinale, car les abus dans certains domaines du droit sont si flagrants et les récits qu'on en fait si choquants que la plupart des traducteurs, une fois en possession du droit de parole, choisiront les voies de l'humanité et de la décence la plus élémentaire. Les exemples cités dans ce texte se rapportent au domaine de l'incarcération des immigrants dans le sud des États-Unis. Ainsi, pour les besoins de l'article, l'engagement positif désigne les efforts exercés dans le but d'aider les personnes arrêtées aux États-Unis (ou ailleurs) pour violation des lois sur l'immigration. Malheureusement, la forme d'engagement préconisée par cet article n'est pas susceptible de se concrétiser, non seulement parce que les traducteurs ne sont pas " censés être » engagés, mais encore parce que les préceptes du droit lié aux violations des lois sur l'immigration sont si arbitrairement observés, si dénués de cohérence interne aux échelons locaux, régionaux, et fédéraux, et si diversement interprétés, qu’ils méritent à peine le qualificatif de "droit".

Mots-clés : traduction, interprétation, incarcération, droit administratif, immigrants sans papiers.
Tous droits réservés ( $\mathrm{C}$ TTR: traduction, terminologie, rédaction — Les auteurs, Ce document est protégé par la loi sur le droit d’auteur. L’utilisation des 2007 services d'Érudit (y compris la reproduction) est assujettie à sa politique d'utilisation que vous pouvez consulter en ligne.

https://apropos.erudit.org/fr/usagers/politique-dutilisation/ 


\section{Activist Translation in an Era of Fictional Law ${ }^{1}$}

\section{Robert F. Barsky}

\section{Introduction: Transgressing Translator's “Norms” in a Realm of Judicial Transgression}

It seems appropriate to discuss what I will call "fictional law," that is, a realm of law that is so deeply rooted in discretionary practices as to not deserve anything evoking a normative sense of judicial practice, in an article about “activist translation,” which suggests at its very inception a sense of transgression. People carry around machine translators when they travel to other countries, and we are becoming increasingly accustomed to speaking our account numbers and the names of things we are looking for into voice-activated "automatic attendants" ("if that is not what you want, please press 4!"). The dream of "machine translation" is precisely to move from language to "linguistic material," and thereby to apparently eliminate the subjectivity of human intervention, to render the transition from one cultural and linguistic realm to another virtually invisible, or at least a simple matter of direct substitution, as though, as Steve Martin quipped in one of his Saturday Night Live jokes about the French language, "it's as though you have a different word for everything!”

Activist translation as I will describe it presumes that translators ought to be involved, engaged, over and above this act of

\footnotetext{
${ }^{1}$ I'd like to thank Sherry Simon for her on-going kindness and intellectual generosity, Vanderbilt University and, particularly, the Center for the Americas research team on immigrant incarceration, and, moreover, all of the translators, law enforcement officials, NGO representatives, lawyers, public defenders and immigrants I interviewed for this project. And for her magic, I'd especially like to thank Marsha Tardy.
} 
substituting one lexical item for another, and I will argue that this could be a very positive development-if the activism is directed to lofty causes. All of this hinges on a degree of good faith, of course, because the "activism" could also actively hurt the person for whom the translator is doing his or her task. In other words, when the "translator" decides to become an "interpreter," a move for which I have argued in the past (1996), there is the danger that the subjectivity of the latter will trump the "objectivity" of the former, with negative consequences. ${ }^{2}$ I am willing to take this risk, to advocate activism over machine-like fidelity, because the abuses in certain realms of law are so egregious and the stories so horrendous that most translators who are given the right to speak out will take the road towards humanity, in my opinion, and my own work has borne out this suspicion. The examples to which I will be referring emanate from the realm of immigrant incarceration in the Southern US, so I'll take positive activism to mean efforts that help people who are arrested in the United States (or anywhere else) to regain their liberty. But what I will consider to be an admirable aspiration is not likely to occur, not only because translators are not supposed to be activists, and indeed are explicitly discouraged from being anything other than "impartial," and because the realm of law that deals with immigration violation is so unevenly applied, so internally inconsistent across local, regional, state, federal and national lines, and so variously construed depending upon the person doing the construing, that it does not really deserve the nomenclature of "law."

So the type of activism I am describing here is for the most part non-existent and discouraged, and the type of law to which it could or should be directed is ostensibly a fiction. Does this mean that translators can serve a positive role in the system? I believe they can. And is there, or should there be, a "system" to adjudicate immigration violations? There is one, yes, and there shouldn't be, or, at the very least, it shouldn't assume anywhere near the form it does now. ${ }^{3}$ But to understand the nature of the system, we need to step back and really examine how it functions, and in the first instance we need to do so from a great distance, not reading either the laws or the ordinances covering the proper

\footnotetext{
${ }^{2}$ I will distinguish between translators and interpreters, therefore, by speaking of the profession as being that of the translator, and the move towards more subjective intervention as "interpreting."

${ }^{3}$ See my introduction in Arguing and Justifying: Assessing the Convention Refugees' Choice of Moment, Motive and Host Country, 2001, for a full articulation of my position on borders.
} 
translation and implementation of immigration violations, but rather we need to truly examine what is occurring in the realm of immigrant incarceration. Once we have done so, it will be clear that one role that the translator could play would be to describe what actually occurs, and not necessarily as an "expert" or even as a "translator," but as someone who is confronted from one day to the next with the flippancy of a system that is ostensibly designed to keep poor people in their place, and this in the name of so called border enforcement and "law."

\section{Speaking from outside the box}

The role that I am assigning to the activist translator, therefore, is one of the insider who actively chooses to act as an outsider by describing experiences from the privileged realm to which s/he has access. But before launching in such a direction, we need to address some basic issues, and consider the concept of being an "outsider" to systems deemed impartial and "blind," as justice is represented. And we need also to consider from whence emanates this assertion, since it defies normative action in the field of translation. So first, what do I know that provides me with the credibility to promote activism in this realm or, to be consistent, what do I have that makes me an appropriate outsider? I am a literature professor who, granted, has brought the critical eye of the outsider to bear upon systems of repression and exclusion, but by definition I am no "expert" and do not wish to be so represented. Rather, I can play the fool from Shakespeare's "King Lear," the clown who, without investment in the dominant discourse of the legal field, can show up at discussion and describe what I have seen. And I can urge the translator, who does have specific knowledge of this realm, to do the same thing, to speak out and describe the experiences s/he has inside of what has been described to me (by translators) as a manifestly unjust system. On what grounds? Using what ideology? The fool can answer that:

The Fool does not follow any ideology. He rejects all appearances, of law, justice, moral order. He sees brute force, cruelty and lust. He has no illusions and does not seek consolation in the existence of natural or supernatural order, which provides for the punishment of evil and the reward of good. Lear, insisting on his fictitious majesty, seems ridiculous to him. All the more ridiculous because he does not see how ridiculous he is. But the Fool does not desert his ridiculous, degraded king, and accompanies him on his way to madness. The Fool knows that the only true madness is to recognize this world as rational. (Kott, 1974, pp. 166-167) 
The Elizabethan-era fool has officially-sanctioned access to power via the king, while in the modern world, a fiction writer like Émile Zola can use the prestige from his literary corpus to provide him access to the newspaper $L$ 'Aurore, where he could say with reference to the Dreyfus Affair in 1889, "this does not make any sense, this is not the whole story, there is not just that." The professor in contemporary society can become an "activist" in similar ways, by using "prestige" from one realm to speak in another, a kind of "abuse" of power which can be put to different uses. I, for example, teach literature and language theory, and as such I cannot cite from cases for which I have acted as a translator, I cannot speak from the perspective of those who have actually endured incarceration, this system of repression and exclusion, this welfare state or psychiatric ward turned steel cage, but I as a privileged professor with knowledge of language studies can mount a research project and examine what I see without any kind of investment in the system, and therefore can, to cite Marc Angenot in an article entitled "What Can Literature Do," work as a literary person does, with a kind "deviance and subversion that is tolerated, using ostentatious language expenditures, and even perhaps a form of satire that is protected by the Powers that be" (Angenot, 2004, p. 227). Once a study is complete, I can also speak out, and as Edward Said suggested in his BBC radio talk for the Reith Lectures on "Representations of the Intellectual," it is worth making a great deal of one's rare opportunities to do so, "catching the audience's attention, being better at wit and debate than one's opponents. For there is something fundamentally unsettling about intellectuals who have neither offices to protect nor territory to consolidate and guard; self-irony is therefore more effective than pomposity, directness more than hemming and hawing" (1993). Granted, says Said, "no one can speak up all the time on all the issues," but "there is a special duty to address the constituted and authorized powers of one's own society, which are accountable to its citizenry, particularly when those powers are exercised in a manifestly disproportionate and immoral war, or in a deliberate program of discrimination, repression, and collective cruelty" (ibid.). The system of immigrant incarceration is an example of this cruelty, which I now take it as a responsibility to denounce, and in doing so call upon translators to denounce it as well if what they have found in working in that system is to them unacceptable. Jean-Paul Sartre wrote:

...the writer is situated in his time; every word he utters has reverberations. As does his silence... I hold Flaubert and the Goncourts responsible for the repression that followed the Commune because they didn't write a line to prevent it. Some will object that this wasn't 
their business. But was the Calas trial Voltaire's business? Was Dreyfus's sentence Zola's business? Was the administration of the Congo Gide's business? Each of those authors, at a particular time in his life, took stock of his responsibility as a writer, and I wish to do so of mine. (1960, pp. 433-434)

But why should I (or the translator) bother to speak out on behalf of refugee claimants, "sans papiers" or illegal migrants in the US and Canada, and why am I insisting that there is a role for activist translators in this realm? Maybe there is nothing to say here; this is after all a perfect system. We criminalize human beings the moment they enter upon our soil, and this after having overtly enticed them here with seemingly un-enforced or unenforceable laws. As one lawyer interviewed in Tennessee indicated to me:

People receive really mixed messages; on the one hand, they stay here and work, and they do the jobs that nobody else wants to do, and they do what their employers tell them to do so that their employee records will make them appear legal. So all of these people are looking the other way, even though their employers know that they are undocumented. This creates a sense amongst illegal migrants that maybe they are sort of legal. So on the one hand, people are afraid all the time because they are illegal, on the other hand, it's hard not to get this mixed message. There is real injustice in the way that the system plays out, because it works in an arbitrary and sometimes really targeted ways, and people can sense that injustice.

So our Wall Street Journal lauds them for their entrepreneurial spirit, our corporations hire them for their work ethic and low hourly wage, our citizens reap the profits of their toil for their devotion. The message is clear: illegal immigrants are great to have around when we need them. And it is, I repeat, a perfect system, because when we do not need them anymore, when they have finished building our stadium, painting our home, weeding our garden, picking our crops, or when they turn out to be human and make the mistakes that the rest of us make when we slip behind the wheel of our automobile en route to an inebriated ride upon the suddenly blurry interstates that provide us convenient pathways to our malls and our suburban retreats, then we can unceremoniously make them disappear through incarceration and deportation, forever. Cheap and available labor that is always in the wrong, human beings who only have the rights we choose to accord, and only as long as we wish to accord them. A perfect system indeed, as perfect as slavery, nay more perfect yet, for they are in the wrong, being criminals, unlike us criminals who physically forced emigration from Africa upon those we 
needed for our dirty work or us criminals who are never wrong because we are so privileged we can gleefully cross any border we wish. And if they are not technically wrong, they are often made out to be wrong because they cannot communicate their rightness, so if we cannot get rid of them for legitimate reasons, we can always claim that they could not make themselves understood in our "language" (and here I mean both national language and also the kind of professional language described in so much of Pierre Bourdieu's work on language and symbolic power).

Chomsky says in his famous NYRB article on "The Responsibility of Intellectuals" that intellectuals ought to speak out because "they are a privileged minority, for whom Western democracy provides the leisure, the facilities, and the training to seek the truth lying hidden behind the veil of distortion and misrepresentation, ideology and class interest, through which the events of current history are presented to us" (1967). This seems inapplicable to the case at hand, because there is no distortion or misrepresentation here: before Congress in the most public kind of way is a proposal to make the first entry into this country by these "illegals" not just a crime but a felony; this opens up the possibility of prison sentences for first "offenders" akin to what we now offer to those who actually commit crimes. A perfect system. Why? Because these people are criminal, people who do what we can do with an American Express card and a passport as a matter of course are criminal if, well, they are not us. If this does not strike us as a perfect system, then we have to say why, which often turns upon our use of language and our moral or ethical process to the more basic questions posed. At that point, we can use Said's approach described in Orientalism, to "use humanistic critique to open up the fields of struggle, to introduce a longer sequence of thought and analysis to replace the short bursts of polemical, thought-stopping fury that so imprison us in labels and antagonistic debate whose goal is a belligerent collective identity rather than understanding and intellectual exchange” (2003). If we are willing to make this move, then we cease to be the detached observers who, in William Butler Yeats’s perfect phrase, "deliberately sip at the honeypots of our minds.”

If, resisting the idea that this system is perfect, the translator decides to act upon his or her experience, which direction should s/he pursue? This is not for me to say, of course, because as I noted from the outset it would depend upon what type of activism the person wishes to engage in. From my own perspective, though, I would suggest the following: first, we must orient our defense of these persons who have 
found themselves doing such hard time for infractions like illegal re-entry after deportation or being an "illegal" or "undocumented person" combined with federal crimes such as the possession of pot, by focusing defense upon the second generation. Immigration into this country must be situated, therefore in deep time. Within the public discourse there already is the idea that America (Canada and the United States) is a land of immigrants, we are all immigrants. But this is not a discourse sufficiently convincing in light of the more "expensive" terms, the terms that trump all other terms, such as "security" or "terrorism." So from a language or propaganda perspective, we need to find ways to trump these latter terms with value-laden ones, particularly in the face of an administration and a judiciary which finds little in ideas of compassion, civility or forgiveness, despite the religious framework within which actions are often undertaken. Here I offer the second generation, the children of the incarcerated people who will grow up in our country without the guidance of the fathers and mothers who help make them whole. When thought of through time, things begin to look a little different. Translators could be very effective in this regard because they can talk about the linguistic integration of families, emphasizing that first-generation issues of language integration are substantively different from those facing the second generation, which generally adopts not only the language but also the idioms and the accents of the place within which they live (hearing Chinese children who have been raised in Montréal speaking with a heavy québécois accent is but one of the more striking examples one could invoke in this regard).

A second approach would be to insist that humans be accorded at least as many rights as institutions, like corporations. Chomsky helps us recall that when Madison spoke of "rights of persons," he meant humans. But the growth of the industrial economy, and the rise of corporate forms of economic enterprise, led to a completely new meaning of the term. In a current official document, “'Person' is broadly defined to include any individual, branch, partnership, associated group, association, estate, trust, corporation or other organization or any government entity," a concept that doubtless would have shocked Madison and others with intellectual roots in the Enlightenment and classical liberalism-pre-capitalist, and anti-capitalist in spirit. These radical changes in the conception of human rights and democracy were not introduced primarily by legislation, but by judicial decisions and intellectual commentary. Corporations, which previously had been considered artificial entities with no rights, were accorded all the rights of persons, and far more, since they are "immortal persons," and 
"persons" of extraordinary wealth and power. Furthermore, "they were no longer bound to the specific purposes designated by State charter, but could act as they chose, with few constraints" (1997). This recollection of where ideas of human rights come from, and their slow dissolution in favor of corporate rights, is everywhere in evidence in how we treat illegals.

A third approach, not currently in the vocabulary, is to call attention to the fact that even if, as Bush said publicly on March 25, the United States is both a "country of immigrants" and "a country of laws," these laws are unrecognizable as such and therefore do not deserve the name. For me, the "laws" according to which illegal immigrants are incarcerated are pure fiction because they stem from actions with such extreme levels of discretion as to not deserve the formal and foreboding nomenclature that law provides, and the people who fall into this net provide a whole new definition of the term "vulnerable population." The situation of incarcerated immigrants, who through lack of resources or knowledge or sheer bad luck land on the wrong side of our omnipresent prison bars, is incomprehensible because it is erected upon unpredictability. For those incarcerated under any of the myriad of recent anti-immigrant and anti-illegal laws, law is no more real than the series of haphazard circumstances that lead to it being invoked; as such, it is neither formalized, predictable nor even clearly linked to the actions which led to its occurrence. For some, this means that these laws do not exist, so for them, this is a perfect system from another perspective; some illegal aliens are never arrested, and they live their whole lives in this country with the knowledge that their children will not live in the betwixt-and-between world that they inhabit. For them, the system offers a life of freedom and even, perhaps, relative comfort. Or, and this is the entirely arbitrary or, they can be accused of domestic abuse, or be pulled over for a burnt-out taillight, and find themselves in the "system" of investigation, incarceration and deportation-for being "illegal." This invariably takes place unless someone steps in and stops the cycle, sometimes through the simplest of acts, sometimes through an act of "activist translation." One way in which translators can become activists is to report their findings and their experiences indirectly, through (say) a researcher engaged in studies relating to their work. In this way, even if their own livelihood depends upon their respecting the rules of their profession, they can nevertheless report on their own experiences deep inside the system. What follows is "their" story, reconstituted from interviews with translators, and also from documents and contextual work that aims to complete the picture. 


\section{Translating and Representing Incarcerated Immigrants}

In the current post 9/11 juncture, immigrants and asylum seekers in the United States and Canada are increasingly spending time in local, state and federal prisons for violation of a host of newly-enacted or newly-enforced laws in a context of heightened security, and this incarceration has as its justification a series of memos, laws, proposed laws and programs which, given their arbitrariness and the high level of discretion that leads to their application, are a kind of pernicious legal fiction. The people who fall into this net, and it is vast, provide a whole new definition of the term "vulnerable population," in part because many of them are either seeking status or are without status, and in part because they suffer from being the "other" who usually has no knowledge of the system that is criminalizing them, little understanding of the language within which the system works, and, minimal ability to make themselves "heard" by the legal instances that could provide judicial relief. This new category of vulnerable migrants is treated according to an almost arbitrary application of complex "laws," in Canada and the US, which have been "on the books" but seldom enforced. "Terrorism," "security concerns," and the constantly re-discovered realization on the part of politicians that "tough on crime" is always easy to sell, have provided the political will to descend the slippery slope towards what Julius Grey has aptly called "totalitarian democracy." "Examples of the laws currently invoked and applied include the "US-Canada Third Country Treaty," which was already present in 1993 with the passage of Bill C-86, and which states that:

46.01 (1) A person who claims to be a Convention refugee is not eligible to have the claim determined by the Refugee Division if the person came to Canada, directly or indirectly, from a country other than a country of the person's nationality or, where the person has no country of nationality, the country of the person's habitual residence, that is a prescribed country under paragraph 114 (1) (s).

This was a kind of virtual clause, something that could be evoked at some point when the ideas contained therein became viable; 9/11 was just the occasion. South of the border, Clinton set the stage for the massive abuses (also justified post 9/11) under John Ashcroft's reign with the 1996 Antiterrorism and Effective Death Penalty Act and the

\footnotetext{
${ }^{4}$ From a talk given at Vanderbilt University in March, 2006, forthcoming in the journal AmeriQuests, www.ameriquests.org
} 
Illegal Immigration Reform and Immigrant Responsibility Act, which significantly expanded "the categories of crimes for which immigrants who had become legal residents were 'deportable' and subject to 'mandatory detention'.” These US laws, which stand behind those which followed, particularly post 9/11, “eliminated the INS's discretion to release certain aliens and require that it detain large numbers of legal resident aliens without setting a bond" (Dow, 2004). But even this is just the tip of the iceberg, because at every step in a process which leads up to incarceration of migrants, sometimes indefinitely, there is a stunning disregard and blatant lack of interest in conveying information useful to people who are being arrested, or in finding out what they themselves would like to express about their case, particularly if this information is expressed in some language other than English.

The instances to which I will refer for a description of this phenomenon arise from a research project on migrant incarceration in the Southern USA, ${ }^{5}$ that deals with cases like the following: Imagine if you will the thousands of people who are behind bars, sometimes for 15 years, for having "illegally re-entered" the country. These are people who may have been in the US for a few minutes, or for a few decades, who in some cases have literally grown up, married and worked in this country, and who may even have American wives who have raised with them their American children. They may have worked for large corporations, like Wal-Mart, or they may have run their own businesses, paying taxes, employing Americans, and contributing to the community. They can live their whole lives in this country, content with the knowledge that their children, who are born in the States and are therefore American, will not live in the betwixt-and-between world that they inhabit, and, if a range of existing laws on local, state and federal levels do not some day join forces to prosecute them, they can thrive in their own version of the American dream. Or, and this is the entirely arbitrary or, one fine day they can be pulled over for the crime of driving while Mexican, as indicated in an interview with a translator who has worked for the police department: ${ }^{6}$ "There is no doubt in my mind that with Latino males, there is obviously a problem with drunk driving, for instance. In Latin America, we don't enforce it as we do here, driving

\footnotetext{
${ }^{5}$ Sponsored as a Workgroup by the Vanderbilt University Center for the Americas.

${ }^{6}$ The interviews cited in this paper are stripped of identifying features of the interviewee, compliant with the Internal Review Board application and approval on file with the author.
} 
while intoxicated, it is a different culture. It is more common than it is here. With the backing of the law, cops are able to stop people and prosecute them, and go from there as far as when they suspect someone has been drinking while driving. So, I think a lot of Latino males are targeted for that. Are just stopped, period.” Once pulled over by, say, a zealous cop who is unsatisfied with the driving certificate that is issued to people in Tennessee in lieu of a regular license, and once the issue of language is presented, things can degenerate quickly: "People were routinely stopped for driving issues and if the person did not speak English, I think they were immediately thrust into the category of suspect and obnoxious and someone who was not welcome to be on the streets. That is the tip of the iceberg. If you can't have a license, it just seemed to touch off an extreme reaction that would feed right into someone's scared view of what immigrants represent." The chain of events that generally follows is frightening; usually the "suspect" is then asked in some incomprehensible version of Spanish if it is okay that their car be searched, a constant source of despair for translators who hear about these episodes, as one of them recounts:

The big issue that comes up in all of the court proceedings and it does directly affect us has to do with the Miranda Rights, and there are some officers out there who think that they speak Spanish. They'll say, and we hear this a lot, "I had a one week Spanish survival course," or they carry this little card... with the Miranda Rights [in Spanish]. Some of them have a few phrases like, "may I have permission to search your car" and others think they speak Spanish when they really don't. They do not even bother to carry around those little items and we are having more and more challenges on that because they, the officers, will try to say in Spanish, "may I search your car?” We had this in a case recently and the guy that had him on the stand was from Meridian, Mississippi and they asked him to say how he would have said in Spanish, "may I search your car?” I was doing the interpreting and I had to stop. I did not know what language he was speaking when he said that. It happened so quickly and as an interpreter, you are always a few steps behind what is going on, you are listening and you are speaking what was just spoken so by the time they got back to English, I was sitting there thinking, what was that... Oh, that was supposed to be Spanish. I mean I had a total blank in my interpretation. I had no idea what he said. And, you know this guy, on the basis of the fact that he thought he was asking and then the other guy sort of smiled. He was nervous and he smiled and said, oops, that means yes, so he searched the car and got the evidence and this. We are just seeing more and more of that. 
The activism of this translator has no equivalent in the courtroom; the judge has to rule upon what is said, the lawyer is hired by one side or another, and the police officer is there to justify the traffic stop and the subsequent search of the car. So the first point here is just a question of Miranda rights, that is, if the suspect replies in the affirmative to the unintelligible question and something illicit is found in the car, then s/he can, say, be taken downtown for being "illegal" and for having had the butt of a hand-rolled marijuana cigarette in the ashtray and a package of rolling papers in the glove compartment (drug "paraphernalia"), be unable to meet bail fast enough to avoid the zealous paper-pusher in the prison who makes late-night phone calls to Homeland Security or I.C.E., be sent to a holding institution (jail, penitentiary) to await deportation, be asked to sign without the presence of counsel a number of documents in English renouncing the custody of their children and admitting to drug abuse and driving while under the influence, and, a few days or months later, find themselves "back" in a country that some of them have not seen for forty years. If this person returns subsequent to deportation in order to, say, continue his or her life, and if s/he happens to have any kind of "felony" charge in the past, which can include any crime involving guns or drugs, then s/he when stopped again, for whatever reason, including a random search, will be sent away for at least eight years. The example I have just given is true, but given the level of discretion could also be made to go away, and this by the fickleness of a police officer. In other words, exactly the same people with exactly the same situations can also be let go, at any point in this process, and indeed they are likely to escape any punishment if anywhere along the line someone stops the procedures, for whatever reason, including the fact that (say) the policeman or jailer or administrator happens to think that these poor people just happen to paint the houses, restock the Wal-Marts, pick the corn, or whatever, in the local community.

\section{Activist Translation}

So how can we approach such a situation, particularly if we are interested in issues of social justice? How can we insert ourselves as linguistic translators at crucial moments, or legal translators in judicial settings, in order to provide at least a semblance of justice in the current juncture? And, to pose the thematic question, what does it mean to do "activist" work in this realm if we are not one of the people directly involved with the system, at whatever level? Is there such a thing as "activist translation" theory or practice, and from where does it emanate? The first answer is right here; like clowns, or professors, or researchers, 
translators could be considered "disinterested" parties, that is, they have no particular claim on the victory of one side or the other in a case against an illegal immigrant. As such, activist translators can without invoking particular details of cases with which they are involved convey to a frankly ignorant general public, ignorant because these facts are never presented, the workings of the system within which they are involved.

The second role for activist translators is in the day-to-day dealings with authorities. Migrants in the so-called First World are criminalized to such a degree as to render virtually any case unarguable, or un-winnable, particularly if there is discretion-sanctioned abuse in the early stages leading to the incarceration. In many cases, as we will see, this abuse is purely linguistic, relating to the simple fact that the immigrants, particularly immigrants without legal papers, are not given the opportunity to "be heard" or even to speak on account of a profound lack of linguistic and cultural interpreters who could intervene at crucial moments of interaction with authority. That translators could make a crucial difference flows from the fact that so much of the problem of migrant incarceration happens on the ground, as they say in NGO circles, that is, on the freeways, in the farming communities, and in places where immigrants are called to appear, such as traffic court. This is where the worst abuses of translation meet the potentially nefarious system of vague laws and ordinances which can ensnare foreigners, and what allows the movement from the traffic violation to the federal indictment often has a linguistic element to it. A lawyer who represents farmworkers, who in the South are mostly illegal immigrants, notes the following:

I have heard of a lot of people that have some kind of traffic offense that then gets them run through the computer, which then reveals that they have immigration holds. Those are most of the people that I talk to. Or the people who don't even have a traffic offense that are entered into the computer and found to have immigration holds. Or people who are entering the courthouse. There's a practice in upper east TN where there's an officer who would schedule Monday in one county, Tuesday in another county, which corresponded to the day when the Spanish interpreter was there, and he would be in the courthouse looking for whoever looked Hispanic. There's no criminal offense in those cases, an immigration agent has the authority to stop any of us and ask us about our immigration status, so far as he is not discriminating based on a constitutionally protected category. So he's not actually allowed to ask all the Mexicans about their immigration status, but if he was asking everyone in the courthouse, then he could 
do that. People also have the right to not answer his questions, but people are so afraid of what's going on, and because of the meshing of the different law enforcement officers and their roles, the officers are playing on that. So these are people who just happen to be in the courthouse paying a ticket can get incarcerated based on that, and then arrested on a prior deportation order.

As is clear from this description, language skills on both ends of this equation exacerbate the problem tremendously, and in fact lead to an actual shift in the legal categories into which people are likely to fall. If an immigrant speaks good English, or if there is a translator present to ensure that this is not just racial profiling, then the chances of escaping from such random identification fishing trips is of course much stronger. So activist translators need to work in both directions, informing the general public, through whichever intermediary is appropriate, as to what is going on, and informing immigrants of their rights. And translators are often the best intermediaries in this sense. ${ }^{7}$ But because the linguistic resources are not usually in place at local levels, inmates cannot benefit from their experience, thus these already criminalized individuals find themselves committing new crimes with each passing moment:

I have heard stories about people who have a partner who has been incarcerated for some allegedly legitimate reason who goes to bring clothes to that person, and gets picked up at the jail after their name is run through the system when they sign in to bring the materials. We had a girl who was taken into custody; she had gone to drop something off at the jail for someone else, and she left her kids in the car for ten minutes while she went in. They wouldn't wait on her quickly, because she was Hispanic, and because she spoke no English, so it took her fifteen or twenty minutes, so they cited her for leaving her kids in the car. She was taken into custody, and landed up in immigration court. The perception of the community is that either these no-reason cases, or low-level misdemeanor citations are being used as a funnel to incarcerate immigrants.

This question of "perception" is crucial to effective law enforcement, another issue that could be addressed by active and articulate advocates who are willing to speak out. Law enforcement officials have no interest in developing contentious relations with local populations, since it makes their job far more difficult and dangerous. For this reason, police

\footnotetext{
${ }^{7}$ I have argued this point in "The Interpreter and the Canadian Convention Refugee Hearing: Crossing the potentially life-threatening boundaries between 'coccode-e-eh,' 'cluck-cluck,' and 'cot-cot-cot’”, 1993, TTR, 6:2.
} 
forces around the country have openly disregarded immigration laws, as we shall see; but once again, the case can be made to them, and on their behalf, by those people who are familiar with cultural tensions and conventions, which generally requires two-way linguistic abilities and convincing levels of knowledge. Eventually, we may not need "specialists," the society will be sufficiently diverse to make any school-age child aware of what needs to be done. So from a broader perspective, the issue is relatively straightforward; if sufficient resources were directed towards the bi or multilingualism of the US, examples like this would find some relief.

People involved in the system also note the degree of ignorance even amongst the general population about the rights we presumably have. As such, there is another level of interpretation which compounds the problem, and has to do with interpreting legal rights across linguistic and cultural boundaries, as another lawyer describes:

The cop is supposed to have to tell the person that he can refuse to have his car searched. But if you pull some guy over that doesn't speak any English, how the hell do you explain it to him, that he doesn't have to consent. I had a federal case where they got permission to search the house. They brought a jailor out who speaks Spanish. She read him the rights in Spanish, and asked if the people in the house understood. So I said, tell me in Spanish what you told them. What she told them was, "you have a right not to use your rights." I said, come on judge, that's not an explanation of rights. It passed muster for that day in court. The evidence wasn't suppressed, but it happens all the time.

This is a crucial point, which deserves mention even in an academic journal like TTR; for an officer in the US (or Canada, although in the latter case rights are less clearly-defined) to search a car, he or she must have probable cause. If there is none, then whatever is found in the course of that search is eligible for suppression, as indicated by a lawyer:

Consent has to be knowing, intelligent and voluntary, and for that, language is critically important, as is age, educational background, there are a number of factors to be considered. This is something we can challenge, and the way to do it is get a Spanish-speaking expert witness who will watch the tape and say "this officer said 'do you want eggs with your toast,' or something that was not 'can I search the car.'” We have had some success with this, but a lot of times courts bypass those requirements and find other reasons to justify the search after the fact, because when there are four or five kilos of cocaine found in the car, the courts are inclined to say "listen, these cops had a hunch, and 
they acted on the hunch.” There are many more cases where I think that we should have been successful, than cases when we really were successful.

More than likely, whatever the officer says, the immigrant will be deemed to have consented, as another lawyer suggested: "The ways in which Spanish-speaking clients-and we see it with consent to search issues when Spanish-speaking clients are pulled over,-even if they don't understand what the officer is saying, there seems to be this desire to appease or consent, and I think that we see that sometimes with our clients, they consent without an understanding. I don't know if it's a reflection of the way that the justice system works in Mexico, or if it's more tied to the culture.”

But here's another way in which the system works against the foreign born, because if there is abuse in this form, deportation itself can trump the legal remedy, as one lawyer explains:

If the police officer has probable cause to believe that the person has committed a crime, he can detain them. If he has no other probable cause and they have not revealed anything about their status, then he cannot detain them, and if he does, then they'll have a civil rights law suit against him. But for all that, if he detains them, even unlawfully, and they do have an immigration hold, and then they get deported, then they're in Mexico, so it's hard to bring a civil lawsuit from there. The other thing that happens is if they come back, then they're unlawfully here again, and it's hard to bring a civil rights lawsuit, even though the rights have not changed, their standing makes it difficult, and puts them at a huge amount of risk to stand for those lawsuits. There's also very few attorneys who want to bring those lawsuits. So there would be a good case if the agent were to profile a person who happened to be a legal permanent resident. If that person were to refuse to reveal her status and be detained, that would be a good lawsuit. But the reality is that people are not that educated about their rights, and they're scared. And they want to end this interaction, particularly if they don't understand English very well.

So even if the immigrant technically has constitutional rights, the trump card of deportation ensures that s/he cannot use them, which leads to the truism that although these individuals may have a better shot at justice at higher level courts, they are unlikely to go much further than the point-of-entry to our legal system, the people doing the arrests, the bookings, and the original decision-making in the jails. And with these individuals, the handicap of not speaking English is paramount. A 
lawyer who works with class action suits provides a sense of the consequences: "In East TN, there has been an agreement on the national level that if you're in a labor dispute and a report is made about you to the Department of Homeland Security, that they will refuse to investigate. It takes the permission of some very high level person to authorize to investigate for you during that dispute, which is ostensibly them saying that we want to encourage people to bring minimum wage law suits, and we're not going to deport them in the middle of the deposition for their lawsuit, even if the defense counsel calls the INS.” And you can just imagine the chances of this happening.

If once the immigrant enters the system he or she happens to be lucky enough to find decent legal representation, in for example the public defenders office, then there is some hope, as long as s/he has not, say, signed away his/her rights before meeting counsel. The process s/he will follow if taken into custody is described here by a public defender:

Immigrants are generally arrested by the bureau of immigration and customs enforcement, a newly created branch of law enforcement that was formerly INS. He is then brought into the federal courthouse, and either through an indictment or a complaint, the public defender's office is notified, and almost 100 percent of the time they qualify for assistance from our office. They are given a statement of their rights, a four or five page document that details the initial proceedings in court, and their basic rights under the constitution. They then appear before a magistrate judge. If there has been an indictment they will be arraigned, which is where a plea of not-guilty is entered. There are no circumstances where you'd plead guilty at that stage. They are then taken to a facility either in Nashville, or somewhere in Kentucky or TN, and then they are processed in the same manner as English-speaking clients. If you don't speak English, you're just out of luck. I don't know of anything for them in those facilities, which are by and large incredibly rural county facilities where the counties have contracts. But there are no federal holding facilities, so the marshals sign contracts with little Mayberry jails, these little dingy county facilities, whose primary source of funding are these contracts with the federal government. A portion of that population will be your low level burglars and repeat D.U.I. offenders who are locked up with people awaiting trial on federal charges. In these places, the guards barely speak English, much less Spanish.

So even the presence of a lawyer on the scene is of marginal value, with much riding upon his or her knowledge of immigrant rights and the availability of a translator, if necessary. But in a system of depleted resources or in the face of the seemingly ubiquitous penury of trained 
translators, so much happens in totally haphazard ways. To hear translators speak of how they landed up in this career path provides some indication of this:

From 1997-2002 that particular community of Latinos in Danville, Kentucky had also had an influx, as many in the southeast have had, of Mexican immigrants mostly, a 200 or 300\% growth in 5 years. These were Spanish-speaking immigrants from Mexico coming to work on tobacco farms and horse farms. So, within the Danville community itself... we had a lot of opportunity, and that is why I started this program, for students to actually talk with native Spanish speakers close by. We had a host of other social service activities that our students could volunteer in. As far as incarcerated people, that is where I began to work with them. Then when I left that position and moved to Nashville, Tennessee, I ended up taking, because it is what was available at the time and I was interested in it, I took a job full time on the staff of the public defender's office in Tennessee.

The problem is that in such an arbitrary system, where a community may or may not have translators depending upon the entrepreneurial skills of particular individuals, there is no way of telling what kind of services will be available. And even if a translator and a lawyer are present, there can still be obstacles to justice in the form of stereotypes or misinformation. "I believe that for cultural reasons immigrants often lie in ways that they do not need to, because that's what they think that they should say, and it destroys their case. It has happened with clients of mine. If I interview them enough I can pick up on this and help them before it's too late. But I have heard about people saying what they think they should say, from their community, for example, and it really screws them up. It's very hard to get someone to admit that they have been lying to you, and to get them on board and to trust you.” But the obstacles do not even end here; the entire system is built on an impersonal sense of simply putting people away, often far from the place where the arrest took place, with huge legal and personal consequences, as one lawyer notes:

As far as visitation, families, undocumented or otherwise, are less likely to visit, because it's an incredibly daunting experience, even for me. For instance, in Bowling Green KY, it's a fifteen minute visit. And Bowling Green is ninety miles away. So you get your family, you go in, there's very restricted hours, you get signed in, you have to produce an i.d., and if you don't produce an i.d. you don't get in. By the time you jump through all of those hoops, the reward is a fifteen minute visit through a mesh screen. It's something, that, I had a guy sentenced a 
few weeks ago, and his girlfriend had no means of transportation. He's at a processing facility in West TN, and she's now in Nashville. So his girlfriend wanted to see him, and we got there at nine at night, it's nine to nine fifteen, and her i.d. was expired. She doesn't have a driver's license, and her i.d. had expired three years ago, and they just said, "you cannot come in." Fortunately, we were able to get her in, but it was difficult. It's an extraordinary obstacle just to get to Bowling Green KY, and it's just exacerbated for Spanish speakers, because it's not like the guard at that facility is going to say "hold on, let me get a translator to come and help you, and to address all of your cultural issues.” KY is a scary place, even for me.

Once they are put away, the suffering grows exponentially, sometimes leading to worsening mental health conditions. In one case, a family feud growing out of the incarceration occurred, leading to an Hispanic prisoner being cut off from everyone he knew on the outside. A priest who knew of the case told me:

I think that his feelings of alienation and isolation have really grown. That has been a really difficult psychological thing, to go for days and days without speaking to anyone. And he's two and a half hours from here. I think that he's having an emotional breakdown. He is not doing well. And it's hard for us to say if he has had previous mental illness. We have tried to get something on his history, but to get anything on him given that he's here illegally is difficult. He didn't have health insurance. At least with English-speaking clients there are obvious sources for health issues, and we get them to sign a release, and we get treatment, evaluation, a whole health history. They might even have undiagnosed conditions. So this guy I'm telling you about seems extraordinarily depressed, but is he more depressed than anyone else would be alone for days in KY? Or are there serious psychological issues, and do we need to get him evaluated?

So the image of ever-growing despair is very real, and it is remarkable the number of ways this is exacerbated or set off by questions relating to communication, which then lead to arbitrary actions committed by officials with unclear levels of discretion who are dealing with populations from different cultures, often without proper legal counsel or proper interpretation. It is a lethal combination. At some point, however, the fiction can become reality, and often with the scribble of a pen upon a page of text which is undecipherable to the person doing the signing. As migrants move through the system, from local to state to federal jails, they are quite literally moved from place-to-place, but also from one set of officials to another, with all the uncertainty this entails. 
And along the way, they can make some terribly consequential mistakes, as another lawyer made clear:

It's still an open question as to how long it is taking people to get into that national loop, and what rights they are giving away before that happens. There's a fairly developed legal rights education system going on in Florence AZ, and places like that, where they enter the National Immigration Detention Center system that will lead to their deportation. But if people are spending 30 to 90 days in Blank county before then, and being asked to sign voluntary departure, they are being asked to sign away custody of their kids, to make all these really important legal decisions without the advice of counsel and without any sense of what their legal rights are, that's very disturbing. And many, many attorneys in this area are unaware of rights immigrants have. So where's the law in all of this? It's there, and it's not there, depending upon how lucky you are, or how well you know the traffic cop, or if you speak the right language, or have the right color of skin. Or not. You can follow the law and head to the courthouse to pay a parking ticket; but while doing so, you can be picked on by a Homeland Security officer who has decided to ask for your status in the country. You can stay out of jail, but when your friend lands in jail, you can find yourself arrested because you went to visit and had your name run through the system after you signed in. The only predictable part of it is that if you "ain't from here," you're a sitting duck in a shooting gallery of arbitrary actions.

At later stages in the process, when the immigrant finds him or herself in the face of an actual judge to determine the consequences of the actions leading up to the sentencing, things seem to be a bit better, if only because there is a formal apparatus for determining the facts of the case, and a set of interpretation and translation norms in effect in the courtroom. And yet, even here discretion sets in, and this unbelievable-but-true description from a lawyer I interviewed is emblematic of the whole situation:

I was in Dayton County, where they had the historic monkey trial at the historic court house. I was on the side of this Hispanic kid who was charged with vehicular homicide; while on his way to work he fell asleep, crossed the center line, hit someone, and killed him. I went down there to represent him. As I'm sitting there, and there are lots of Hispanic folks because it's farm country. They were looking for someone to translate, and so someone says "Go get Paco, somebody said Paco is around.” Paco had done eight months in jail and had become the darling of the sheriff and the judge, so they went to go get Paco. I'm not saying anything, I'm just from out of town, visiting, I'm 
going to hang out here to see what's happening. So I go up and stand next to him while he's translating, and I'm just saying “don't mind me, I'm just standing here.” So the judge says to Paco, "You understand son, you have the right to go to trial." Paco translated this as: "You don't want to go to trial, you'll get more time.” The judge says "You have a right to have a lawyer with you today." Paco says, "You can have a lawyer, but that means that they are going to continue it, and you don't want to do that, best thing you can do is plead guilty." So I finally got the judge's attention and said, "Ah, pardon me judge, I'm not so sure Paco is doing a real good job translating!” It may be a problem, it may not be a problem, but that was what was passing for translation. And I don't think it has changed, even though there are new rules, where you have to have someone certified. But the rule is, if you don't have a certified translator, then you have to have a registered translator. And if you don't have a registered translator, you can have uncle Joe. And if you don't have uncle Joe, you can have Paco. It just keeps coming down until Paco gets right back into court.

The image here is one where bad faith can prevail and destroy a life, and the life of the family to which the person is connected. But even when there is good faith, things can go awry, often through a penury of resources, as one translator pointed out:

Well, I realize there is a whole body of literature on interpreting and I have a colleague who has been instrumental in publishing a lot about that. I think it has changed for the better in terms of people being aware of some of the issues of interpreting, how difficult it is to do it well, and how without it how unfair it is to everyone, particularly the dependent. What has happened in Tennessee is typical of what has happened nationwide where you have a law enacted so you have to scramble to get people to interpret. That is the positive side, that there is a growing awareness of what it takes to have skill of interpreting and translation. The negative side is that in that scramble, a lot of people are underserved and there are myriad of cases... which involve someone not doing it right. When I worked at the public defender's office there was, in spite of this lobbying in current so forth you were required to have a skilled interpreter, certified interpreter employed. Metro had someone on staff who had a pager and was called from court room to court room all day long as needed to interpret, sometimes to the jail as well. This person was not qualified. He was reportedly bilingual but he was not qualified. In fact, when he tried to get qualified, he failed the exam, the first one, the written one. And yet, he was called on for years. He is no longer there. It is really a pressing need and I am just talking about Spanish, which is the majority of the cases ... . It is illustrative, I think, of how difficult, it has become kind of a many-headed monster and unfortunately it is one easy target for 
the courts to say it is a problem with immigration. We have to spend so many resources getting an interpreter and you can't get a good interpreter, we don't have enough. It just adds to the conflict, the tension, the whole mix. It is kind of a mixed bag. I've seen some positive changes and some negative ones, some pressing ones that have not yet been addressed.

This leads to a cautionary note, which is that efforts at improving this system which try to induce or introduce "caring” and subjectivity may not be of much help unless there is the institutional apparatus behind the amendment, and some formal and recognizable set of norms that apply across the board. The work of legal theorists like Robin West or Anne Coughlin, therefore, should be read with a degree of cynicism because of the vague categories of compassion and fairness to which they defer. For example, Coughlin suggests that if in cases of extreme marginality and therefore vulnerability individuals are given the chance to speak openly, they will challenge traditional narrative boundaries that exist in the legal domain; but this assumes that these outsiders will not only speak, but also be "heard," suggesting that they will be able to create, pace Pierre Bourdieu, a new common sense and integrate within it the previously tacit or repressed practices and experiences of an entire group, investing them with the legitimacy conferred by public expression and collective recognition. In cases of migrants who have found themselves on the wrong side of the discretionary fence, the ability to be "heard" is far from obvious because it takes a kind of political or judicial will to allow such things to occur, a will that would demand, quite literally, a "good king" and, to be blunt, unless you get a judge in rehab, as in the example above, we really do not have one. All that we do have is a rough-and-tumble group of administrators working nightshifts in prisons, desk shifts in jails, or patrol shifts in police cars who, if the donuts are not fresh, the night is too long, the noise is too loud or the O'Reilly Factor too convincing, just might decide to make all of the worst nighttime phone calls to Homeland Security, I.C.E. or the FBI, those little gestures that can wreak such havoc. If the stories about this were not so dreadful, they would be comical, particularly as told by some lawyers-and this one is worth quoting at length on this issue:

The problem is, you can take 15 illegal immigrants out in this parking lot, put them in a van, and start calling the police on them, one after another over a twenty-four hour period. Some of them will be taken out, booked, make bond, and they're gone. Others will be taken out, get booked, and be picked up by INS, and it's only because Bubba came out on the midnight shift, and Bubba, who is making $5 \$$ /hour to 
be a jailer, and the only reason you'd take that job is because you want to fuck with people, why would you want $\$ 5 /$ hour in a dungeon? You are indoors, you ain't seeing the sunshine, and you're dealing with unhappy miserable people who don't want to be where they are. Bubba don't like the fact that these damned Mexicans are walking around here anyway, so Bubba, if they don't speak good English, is calling INS. And there's no rhyme or reason. You get one guy on aggravated assault who gets a bond and goes home, you get another for driving with no license and he gets an INS hold.

Robin West in some ways speaks directly to this issue in her Caring for Justice, a text that demands not only a new form of justice for the treatment of specifically female persecution, but a whole new approach to justice which would refuse the Kantian insistence upon the primacy of a blind figure of justice who in an unbiased, uncaring fashion simply weighs the facts of each case as though they were so many widgets with values prescribed by an overriding and of course fundamentally masculine economic system. But here again, without a strong sense of how this "care" is to be concretely and consistently defined (and by the definitions West offers it is difficult to see how they could be), the tenets of classical liberal law which she finds appealing are not likely attainable. In other words, to hope that "the pursuit of justice, when successful, must also be caring, and the activity of caring, when successful, must be mindful of the demands of justice” (24) is in some ways contradictory. If anything, caring can go in the wrong direction, with a population that is so profoundly criminalized, as one lawyer indicated in an interview:

These are folks who to a large extent came here for the sole reason of earning enough money to send to mama. And they are doing that. And then, on Friday night, they are there with a car. They would never have had a car where they're from. \$500 gets you a damned good usable car here, and you couldn't touch one for \$500 in Mexico. And they can drive it. License? Maybe. Then some clown shows up drunk one night and sold one of the guys a $\$ 200$ pistol. There's a really big tradition in Latin America, where if something is happening that is good, then you fire your pistol off. This guy is not a threat to the community. We take the pistol away from him, we tell him why we don't do that, and he goes on. Because the reason they are in jail is the same reason why my Caucasian clients are in jail,-drinking, drugging and being stupid-and just because you come from Mexico and are here to send money home doesn't alleviate any of those three conditions. But what eventually happens to them if arrested depends upon who is working in the jail as to whether, when you are looked up on the computer, that there's a 
little line on the computer that says 'hold for I.C.E.' When that happens, you are screwed.

Screwed indeed. Screwed because he is Mexican, screwed because he speaks Spanish, screwed because of his customs, screwed because he is here to send money to Mama, screwed because somebody forgot to tell us that translation is not just words, and these people, these "illegal migrants," are not just foreign elements in a system overseen by the rule of law, they are not just incomprehensible Hispanophones in an otherwise comprehensible world. They are human beings whose faults are as vast as our own, and whose rights should be of an equal magnitude.

\section{Conclusions for the "Activist"}

Consistent with the "activist" agenda here, it seems appropriate to conclude with some concrete suggestions, over and above the general gist suggested thus far. In a system so fundamentally flawed, I feel misgivings at offering any kind of band-aid suggestions, because they might be considered as contributions to "reforming" or "upgrading" the current approach. Given the basic arguments of this article, nothing could be further from my objective because virtually everything about the current approach is unjust, hurtful and un- or anti-humanity. Nevertheless, to help reduce the suffering of those who are or about to be subjected to the whims of the current system, there are some concrete ways to improve approaches to communication, interpretation and translation.

First, from a general perspective, we need to promote and value bilingualism and multilingualism in all institutions in our society. We need in a concomitant way to value the diversity that immigrants bring to our nations. With this valuing will come the need on the part of individuals and institutions to recognize, acknowledge, and disseminate the importance of quality interpreting and translation and what that means.

Second, and to actualize the first, we need active training, recruitment and promotion of translation and interpreting at all levels of education and government. Schools should all offer several languages of instruction, at all levels, and translation studies should be encouraged in institutions of higher learning. 
Third, we need to look beyond our borders and form links with governments of nations from which our immigrants come, which is to say every country in the world; in a general way this means the promotion of the United Nations and similar internationalist efforts, but more specifically we need to promote ties between consulates, embassies, international agencies, NGOs, even international corporations, and we need to lobby them to get involved with the citizens of their countries who are now residing elsewhere. As one translator said: "When I was working in the public defender's office there were representatives from the Mexican consulate in Atlanta who came to meet with some of the attorneys to let them know that they are there for incarcerated Mexicans, and that the clients would have access to their office. They would be able to call and should call for help, even if they were undocumented."

Fourth, those who are in the translation field need to drop the façade of "impartiality" when they are faced with clear and obvious abuses of power. This does not have to happen every day, it does not have to implicate everyone in this realm; but it should be discussed, and "activism" in this realm ought to be discussed, as it is in this issue of TTR.

Fifth, given that more than 2,000,000 people sit inside of US prisons on any given day, we need to advocate language instruction and provide materials to incarcerated people. The longer term goal ought to be to liberate the vast majority of these people and to re-think how we punish non-violent or mentally-ill individuals. But in the meantime, something could be done about the horrendous conditions of institutions which are glorified sterile cages.

Even these small efforts, which would place translators and interpreters throughout our offices, police forces, schools and companies, and would as a consequence raise the levels of expectation and competence and training, would help alleviate some horrendous suffering, some purposeless acts of violence and repression, and, for those caught up on the wrong side of the steel fence, would at least provide some ability to communicate outside of the horrors of one's own troubled mind.

Vanderbilt University 


\section{References}

ANDREAS, P (1998). “The U.S. Immigration Control Offensive: Constructing an Image of Order at the Southwest Border" in M. M. Suarez-Orozco (ed.). Crossings: Mexican Immigration in Interdisciplinary Perspectives. Cambridge, MA, Harvard University Press.

ANGENOT, M. (2004). "What Can Literature Do?” in Barsky, ed., "Marc Angenot and the Scandal of History." Yale Journal of Criticism, 17:2, pp. 163-182.

BACA, J. S. (1981). "Past Present” in Franklin, H. B. (ed.), Prison Writing in $20^{\text {th }}$ Century America. New York, Penguin Freedman.

BARSKY, Robert F, ed. (2004). "Marc Angenot and the Scandal of History.” Yale Journal of Criticism, 17:2, pp. 163-182.

- (2001). Arguing and Justifying: Assessing the Convention Refugees' Choice of Moment, Motive and Host Country. Aldershot UK; Philadelphia, Ashgate P.

- (1996). "The Function of the Intercultural Interpreter." The Translator: Studies in Intercultural Communication, 2:1, pp. 45-63.

- (1994). Constructing a Productive Other: Discourse Theory and the Convention Refugee Hearing. Amsterdam/Philadelphia, John Benjamins.

— (1993). "The Interpreter and the Canadian Convention Refugee Hearing: Crossing the potentially life-threatening boundaries between 'coccode-e-eh,' 'cluck-cluck,' and 'cot-cot-cot'." Traduction, Terminologie, Rédaction (TTR), 6:2, pp. 131-156.

BASCH, L., N. GLICK SCHILLER, and C. SZANTON BLANC (1994). Nations Unbound: Transnational Projects, Postcolonial Predicaments, and Deterritorialized Nation States. Langhorne, Penn., Gordon and Breach.

BURKE, S. (2003). "Mexican Drug Cartels Making a Hub of Drug Network.” The Tennessean, July 27. 
CAPPS, R. et al. (2002). "The Dispersal of Immigrants in the 1990s." Washington, D.C., The Urban Institute.

CHAVEZ, L. R. (1992). Shadowed Lives: Undocumented Immigrants in American Society. New York, Harcourt Brace Jovanovich College Publishers.

CHOMSKY, Noam. (1997), "Market Democracy in a Neoliberal Order.” ZMagazine on-line, cited at http://www.zmag.org/Zmag/articles/chomskysept97.htm

- (1968). "The Responsibility of Intellectuals," published in The New York Review of Books, February 23 ${ }^{\text {rd }}, 1968$ and available on-line at The Responsibility of Intellectuals, by Noam Chomsky.

CORNFIELD, D. et al. (2003). Final Report of the Immigrant Community Assessment. Nashville, TN, Metropolitan Government of Nashville and Davidson County.

COURRIER, K. et al. (2004). "Crossing Borders: The Impact of Immigration.” Washington, D.C., The Urban Institute.

DE GENOVA, N. P. (2002). "Migrant Illegality and Deportability in Everyday Life.” Annual Review of Anthropology, 31, pp. 419-448.

DEMSKY, I. (2005). "Recruits Add New Hues to Those who Wear Blue.” The Tennessean, January 16.

DOW, M. (2004). American Gulag: Inside US Immigration Prisons. Los Angeles, University of California Press.

- (2002). "Endgame: Detention and Removal Strategic Plan 2003-2012.” Washington DC., Dept of Homeland Security, Bureau of Immigration and Customs Enforcement, Detention and Removal Operations.

FOUCAULT, M. (1977). Discipline and Punish. New York, Pantheon Books.

GLICK SCHILLER, N. (2003). "The Centrality of Ethnography in the Study of Transnational Migration: Seeing the Wetland instead of the Swamp" in N. Foner (ed.). American Arrivals: Anthropology Engages 
the New Immigration. Santa Fe, NM, School of American Research Press.

HAGAN, J. (1998). Commentary on P. Andreas, “The U.S. Immigration Control Offensive: Constructing an Image of Order at the Southwest Border” in M. M. Suarez-Orozco (ed.). Crossings: Mexican Immigration in Interdisciplinary Perspectives. Cambridge, MA, Harvard University Press.

HALLINAN, J. T. (2001). Going Up the River: Travels in a Prison Nation. New York, Random House.

HAMILTON, L. S. (1985). "A Profile of the Mexican Migrant and His Social and Cultural Adaptation to a Federal Prison.” Journal of Offender Counseling, Services and Rehabilitation, 9:3, pp. 7-19.

HAMILTON, L. S. (1985). "Campesinos and the Undocumented Inmate: Comparisons and the Impact of Prison.” Migration Today, 13:3, pp. 19-29.

HAYES, H. (2001). US Immigration Policy and the Undocumented: Ambivalent Laws, Furtive Lives. Westport, CT, Praeger Publishers.

HERNANDEZ-LEON, R. and V. ZUNIGA (2000). “ 'Making Carpet by the Mile': The Emergence of a Mexican Immigrant Community in an Industrial Region of the US Historic South.” Social Science Quarterly, 81:1, March, pp. 49-67.

HEYMAN, J. M. (2001). "Class and Classification at the U. S.-Mexico Border.” Human Organization, 60:2, pp. 128-140.

"ICE Detention and Removal Operations." US Immigration and Custom Enforcement. http://www.ice.gov/graphics/dro/index.htm. October 13, 2004.

KOTT, Jan (1974). Shakespeare Our Contemporary. New York, NY, Norton.

LOTSPEICH, K et al. (2003). A Profile of the Foreign-Born in the Nashville Economic Market. Washington, D.C., The Urban Institute. 
MAHLER, S. J. (1995). American Dreaming: Immigrant Life on the Margins. Princeton, NJ, Princeton University Press.

MALONE, N. (2003). “The Foreign Born Population: 2000.” Washington, D.C., U.S. Census Bureau.

MASSEY, D. S., J. DURAND, and N. J. MALONE (2002). Beyond Smoke and Mirrors: Mexican Immigration in an Era of Economic Integration. New York, Russell Sage Foundation.

MASSEY, D. S. (1987). Return to Azatlan: the Social Process of International Migration from Western Mexico. Berkeley, University of California Press.

MIRANDE, A. (1985). The Chicano Experience: An Alternative Perspective. Notre Dame, IN, University of Notre Dame Press.

NATIONAL CONFERENCE OF STATE LEGISLATORS (2001). "Building the New American Community Initiative: A Summary." Washington, DC.

NOVINGER, T. (2001). Intercultural Communication: A Practical Guide. Austin, TX, University of Texas Press.

ONG, A. (1996). "Cultural Citizenship as Subject-Making: Immigrants Negotiate Racial and Cultural Boundaries in the United States." Current Anthropology, 13:4, pp. 737-763.

PIORE, M. J. (1979). Birds of Passage: Migrant Labor in Industrial Societies. New York, Cambridge University Press.

RHODES, L. (2001). "Toward an Anthropology of Prisons.” Annual Review of Anthropology, 30, pp. 65-83.

SAID, Edward. (1993) Introduction to the BBC Reith lectures, "Representations of the Intellectual," available at http://www.bbc.co.uk/radio4/reith/reith_history.shtml

- (2003). Orientalism. London, Vintage Books, available on-line at: http://www.princeton.edu/ paw/web_exclusives/plus/plus_110503orie nt.html 
SARTRE, Jean-Paul (1960). 'Présentation des Temps modernes,' Situations, II, pp. 12-13; trans. Françoise Ehrman, 'Introduction to Les Temps Modernes,' Weber, Paths to the Present, New York, pp. 433-34.

- (1988). What is Literature? Edited by Steven Ungar. Cambridge, Harvard UP.

SOLIS, J. (2003). "Re-Thinking Illegality as a Violence Against, not by Mexican Immigrants, Children, and Youth.” Journal of Social Issues, 59:1, pp. 15-31.

VAN GENNEP, A. (1960). The Rites of Passage. Chicago, University of Chicago Press.

WACQUANT, L. (2002 ). "The Curious Eclipse of Prison Ethnography in the Age of Mass Incarceration.” Ethnography, 3:4, pp. 371-397.

WELCH, M. (2002). Detained: Immigration Laws and the Expanding INS Jail Complex. Philadelphia, Temple University Press.

ABSTRACT: Activist Translation in an Era of Fictional Law - This article proposes that activist translators be involved and engaged in those legal realms, such as the treatment of "illegals" or undocumented migrants, because this is an area in which translators can act as true intermediaries, over and above the act of substituting one lexical item for another; however, this form of activism, like other discretionary activities, needs to be directed to lofty causes, such as upholding the human rights of those most excluded by our society. In other words, alongside of the activism must come good faith, because "activism" could also actively hurt the person for whom the translator is doing his or her task. In other words, when the "translator" decides to become an "interpreter," there is the danger that the subjectivity of the latter will trump the "objectivity" of the former, with negative consequences. This article advocates activism over machine-like fidelity because the abuses in certain realms of law are so egregious and the stories so horrendous that most translators who are given the right to speak out will take the road towards humanity and basic decency. The examples to which I will be referring emanate from the realm of immigrant incarceration in the Southern US, so for the purposes of this article positive activism points to efforts that help people who are arrested in the United States (or anywhere else) for violations of immigration laws. Regrettably, the kind of activism for which this article advocates is not likely to occur, not 
only because translators are not "supposed to be" activists, but also because the realm of law that deals with immigration violation is so unevenly applied, so internally inconsistent across local, regional, state, federal and national lines, and so variously construed depending upon the person doing the construing, that it does not really deserve the nomenclature of "law."

\section{RÉSUMÉ : La traduction engagée à une époque de droit fictif - Cet} article propose que les traducteurs militants s'engagent dans les domaines du droit tels que le traitement réservé aux immigrants clandestins ou sans papiers, car ils peuvent y agir en tant que véritables intermédiaires, au-delà de l'acte de substitution d'un élément lexical par un autre. Cependant, cette forme d'engagement, comme toute activité discrétionnaire, doit être pratiquée pour des causes élevées, telles que la défense des droits de l'homme chez les exclus de la société. En d'autres mots, l'engagement doit être accompagné de bonne foi, parce que «l'engagement » peut aussi nuire activement à la personne pour laquelle le traducteur accomplit sa tâche. Autrement dit, lorsque le «traducteur » décide de devenir " interprète ", la subjectivité du second risque de l'emporter sur " l'objectivité » du premier, ce qui peut engendrer des conséquences néfastes. Cet article préconise l'engagement plutôt que la fidélité machinale, car les abus dans certains domaines du droit sont si flagrants et les récits qu'on en fait si choquants que la plupart des traducteurs, une fois en possession du droit de parole, choisiront les voies de l'humanité et de la décence la plus élémentaire. Les exemples cités dans ce texte se rapportent au domaine de l'incarcération des immigrants dans le sud des États-Unis. Ainsi, pour les besoins de l'article, l'engagement positif désigne les efforts exercés dans le but d'aider les personnes arrêtées aux États-Unis (ou ailleurs) pour violation des lois sur l'immigration. Malheureusement, la forme d'engagement préconisée par cet article n'est pas susceptible de se concrétiser, non seulement parce que les traducteurs ne sont pas « censés être » engagés, mais encore parce que les préceptes du droit lié aux violations des lois sur l'immigration sont si arbitrairement observés, si dénués de cohérence interne aux échelons locaux, régionaux, et fédéraux, et si diversement interprétés, qu’ils méritent à peine le qualificatif de « droit ».

Keywords: translation, interpretation, incarceration, administrative law, undocumented migrants.

Mots-clés : traduction, interprétation, incarcération, droit administratif, immigrants sans papiers. 
Robert F. Barsky: Professor of English, French and Comparative Literature, Furman Hall, Vanderbilt University

Email: robert.barsky@vanderbilt.edu 